\title{
Ayurveda awaits a new dawn
}

\author{
GL KRISHNA
}

\begin{abstract}
Ayurveda is a valuable legacy bequeathed to us by ancient Indian sage-physicians. The present paper discusses the epistemology of this ancient science and the misconceptions surrounding it. Diligent research, both theoretical and experimental, in the twentieth century could have ensured the graduation of this proto-science into a full-fledged science. Instead, epistemological misconceptions and intellectual sloth have thwarted its refinement and progress. The paper appeals for an epistemological break that would facilitate an evidencebased appraisal of Ayurveda's theories and practices. Such an appraisal would help realise Ayurveda's full potential in serving India's healthcare needs, especially at the level of primary care.
\end{abstract}

Keywords: Ayurveda, epistemology, stagnation, misconception, revival

Humans are natural explorers. Since times immemorial, they have zealously explored their natural surroundings with a view to better living conditions. This zeal helped primitive humans get a vague sense of the workings of things around them: "If so and so is done, so and so happens". They were, of course, not very critical in their associations of cause with effect. In some cases it was easy to link them; in some others, erroneous ideas were soon corrected by experience. But there remained many cases where associations were wrong, but not sufficiently wrong or so obviously wrong as to be detected. In such crude associations and corrections are to be found the germinal stages of science (1). Charaka-Samhita expressly states that Ayurveda had its real origins in those prehistoric times (2:30:27).

While food, shelter, and safety were the immediate preoccupations of primitive people, illness and death were grave concerns too. They tried their best to ameliorate them. Sick animals feeding on select plants which they normally

Author: GL Krishna (gl.krishna@yahoo.com), Ayurveda Physician and Independent Researcher, Malleswaram, Bengaluru, 560003 INDIA

To cite: Krishna GL. Ayurveda awaits a new dawn. Indian J Med Ethics. Published online first on December 2, 2021. DOI: 10.20529/IJME.2021.093.

Peer reviewer: An anonymous reviewer

c Indian Journal of Medical Ethics 2021 never ate must have caught the attention of early observers who sought to apply similar remedies in human illnesses. Alongside this, the obvious fears and anxieties of their situations made them appeal for help to the awe-inspiring high heavens. Charms and incantations were thus born, ironically, twinned with primitive scientific thought. After all, these were responses - one emotional and the other intellectual - to the same distressing stimuli. The first priest, it is figuratively said, was also the first medicine man.

\section{The Vedic origins of Indian medicine}

Primitive human speech may have been eked out with gestures and signs along with a few monosyllabic sounds mimicking those of birds and animals. Several millennia must have elapsed before these sounds graduated to become agglutinative and later, inflexional languages like Sanskrit, Greek and Latin. With the evolution of these languages came the surest way of transmitting knowledge, beliefs, and thoughts across generations. In ancient India, Vedic Sanskrit achieved this feat with remarkable flair.

The Vedas are said to have been composed in the 2nd millennium BCE (3). The Atharva Veda was more concerned than the other Vedas with man's health and his struggle against illnesses. Its Kena Sukta refers to the "wonderful anatomy of the human body" and lists body-parts prefacing each hymn with the poetic question "Who designed it?" Apart from fire rituals and invocatory hymns addressed to the gods, Atharva Veda refers to many medicinal plants that were employed in treating illnesses. The large body of knowledge on the healing properties of plants, derived from observations on life and environment, finds codification in its curative hymns (4). No wonder it became Ayurveda's cultural precursor (2:30:21).

\section{Atharva Veda to Ayurveda}

Although the beginnings of empirical medicine can be clearly seen in the Atharva Veda, its approach to therapeutics was predominantly faith-based. Over the span of a few centuries (800-100 BCE), reason came to gradually replace faith and when this transit achieved a marked finality, the classics of Ayurveda were born (5).

The Charaka-Samhita uses two remarkable words to characterise the distinctness of these two approaches: Daivavyapashraya bheshaja, meaning faith-based therapeutics; and 
Yukti-vyapashraya bheshaja, meaning its reason-based variant (6:8:87). Ayurveda acquired its individuality through the latter. In gradually transiting from faith and magic to evidence and reason, the pioneers of Ayurveda had accomplished a paradigm shift that marks the beginnings of science consciousness in India (7). The heterodox intellectual traditions of Buddhism too must have played a role in catalysing this shift (4).

The switch from the predominantly faith-based therapeutics of the Atharva Veda to the predominantly reason-based form of the Ayurvedic classics did not happen as a single disruptive event. It happened over a period of time as a gradual process. A change resulting from such a process, though not unremarkable for the path-breaking turns it takes towards scientific advancement, should still be expected to retain certain ideological vestiges. Daivavyapashraya practice remained as a vestige in the Ayurvedic classics. Charaka's repeated emphasis upon reason (yukti) is unmistakable throughout his text. He says rather sweepingly in one place: "Vina tarkena ya siddhih yadrichcha-siddhireva saa" (8:2:28). Therapeutic success that ensues without proper ratiocination is a mere fluke!

\section{The epistemology of Ayurveda}

An enormous amount of empirical data related to diseases and their cures, compiled presumably by generations of ancient healers, some of whom might have been roving physicians - the Chaarana vaidyas or Charakas - reached the hands of the early theoreticians of Indian medicine (7). After outgrowing the magico-religious outlook of the Atharva Veda, these theoreticians were now faced with the enormous intellectual challenge of rationally processing this empirical data. Driven by the momentous challenge, those ancient doctors were led to develop serious interest in such questions as the veracity of experience, its verifiability, and generalisability. These questions are essentially epistemological. The Charaka-Samhita therefore contains extensive discussions on epistemology, strikingly original and consistent with the needs of medical science (6:8:15-67). Some scholars are in fact led to believe that the Nyaya-sutras, the Indian philosophical system of logic, was constructed on the basis of the epistemological discussions contained in Charaka-Samhita (9).

Both Charaka-Samhita and Sushruta-Samhita, the two primary sources of Ayurveda, emphasise that a medical pronouncement can be deemed authoritative only when it is based on a rational evaluation of verified experience. Sushruta says that the medical interventions his text suggests are trustworthy not merely by virtue of their being efficacious in his personal experience (pratyaksha phaladarshana); their trustworthiness emanated from the fact of their being endorsed by the standard mind of the community (agama-siddhatva) (2:11:27)(10:1:75). This is perhaps the earliest reference to the indispensability of peerreview in generating and verifying medical knowledge.
Medical anecdotes graduating into generalisable evidence after careful deliberations by experts appears to have been the cornerstone of clinical medicine contained in the Ayurvedic classics (6:8:15-67). At least half-a-dozen such conferences of experts have been documented in CharakaSamhita. Interestingly, the text sheds light on the processes of generalisability and theorisation too: "A theory acquires conclusiveness only when it is examined from all sides by multiple investigators and gets readied by rational substantiation" (6:8:37).

This method was scrupulously followed by later Ayurvedic texts. Vagbhata (6th century CE) and Sharngadhara (14th century (E) also emphasise it. When new medicinal formulations were discovered, their inclusion within the classical corpus necessitated a strict adherence to these norms. Dalhana (11th century CE), in his commentary on Sushruta-Samhita, endorses two newly introduced ironcontaining formulations in the management of anaemia (11:44:23-4). While expressly conceding that these new formulations were not part of the original text, he justifies their inclusion on two grounds: "One, we have verified that they are extremely efficacious; and two, their efficacy has been confirmed by our guru as well." Thus, it becomes abundantly clear from an appraisal of Ayurvedic texts that their pronouncements on medical therapies stand upon the twin pillars of verified experience and a rational evaluation of it. Authoritative treatises served as records of such verified and logically systematised medical experience (6:8:83).

But their aspiration to have their therapies rationally substantiated had a formidable handicap. Although the Ayurvedic pioneers realised the importance of biological understanding of health and disease for rational medical practice, their grasp of this subject was understandably rudimentary. Cadaveric dissection helped them study the anatomy of body parts, but only superficially. The scraping of bloated bodies obscured the anatomy of soft parts but provided reliable information about hard parts such as bones and teeth (12). Their physiology could go only as far as common sense permitted; elsewhere, they advanced conjectures mostly revolving around the dosha theory. The brain was not connected with mental activities, kidneys had no role in urine formation, and the lungs had vague functions unrelated to respiration.

Inadequate understanding of physiology and pathology are major hindrances in rationally evaluating medical therapies. Doctors using a given term were often talking about different diseases entirely. For example, even today there is no consensus amongst Ayurvedic scholars about the disease called vatarakta (13). Some identify it with gout, others with rheumatoid arthritis, and yet others see in its description a reference to peripheral vascular disease! Only when accurate, scientifically based diagnoses became common about 100 years ago could doctors begin to effectively evaluate treatments. However, they still had to determine how to best evaluate a treatment (14). 
Because of these handicaps, Ayurveda today retains relevance only as a system of clinical medicine and not as a system that can administer treatments based on an appraisal of the underlying pathophysiology of illnesses (internal medicine). Its treatment, despite popular claims to the contrary, remains syndromic and not etiological. In addition to valuable observations relating to health promotion, the classics of Ayurveda house a rich repertoire of syndromes and promising prescriptions. Enhancing the value of this knowledge-treasure by uncovering its biological bases is a work that remains to be done (15).

There is another point to be alluded to before closing the discussion on classical Ayurvedic epistemology. Despite an unambiguous switch to rational modes of thinking, Ayurveda's extrication of its therapeutics from the earlier magico-religious mores was never complete. As pointed out earlier, elements of Atharva Veda practices like mantra-tantra were retained in the Ayurvedic texts, albeit as occasional vestiges. Religious beliefs like reincarnation were advanced as rationally sustainable ideas (2:11:30-32). It would, however, be imprudent to have an exaggerated view of these aberrations because even the most rational of endeavours should, after all, be expected to remain a citizen of its time.

\section{Ayurveda's stagnation}

The almost two millennium-period between the 8th century BCE and the 10th century CE witnessed Ayurveda's great strides of scientific adventurism (5). Vagbhata summarised, enhanced, and updated (yuga-anurupa) the classics of Charaka and Sushruta.

Updated works on diagnosis and pharmaceutics continued to appear in medieval times at regular intervals. While clinical medicine achieved considerable enrichment with the discovery of new herbs and mercurials, advances in the biological understanding of health and illness remained markedly scanty. The dosha theory was treated as a perfected biological law that could adequately explain all physiological and pathological states; a flexible theory had degenerated into a sophisticated dogma.

Subservience to the written word and textual authority, reinforced by the societal effects of caste hierarchy and mystical philosophies, gradually replaced the spirit of scientific adventurism and enquiry that characterised the work of Ayurvedic pioneers (12). The grave socio-political unrest that India witnessed during the second millennium CE due to Islamist onslaughts only worsened the situation for pursuits that required team-effort and collaboration for their development (16). As a sad consequence of all these, Ayurveda stagnated.

\section{Modern misconceptions and their influence in stifling Ayurveda's progress}

At the dawn of the twentieth century, the hope of a revitalisation of Ayurveda's scientific traditions was renewed.
Its classical spirit of yukti-vyapashraya deserved and necessitated such revitalisation. But that was not to be. Understanding the reason for this frustrated hope first requires a knowledge of Ayurveda's interactions with the Indian philosophical systems.

The Samhitas of Charaka and Sushruta developed in an intellectual milieu that was loaded with philosophical ideas and speculations. Charaka, in his endeavour of rationalising therapeutics, relied heavily upon philosophical systems, especially the Sankhya and the Nyaya-Vaisheshika. While the triguna concept was bequeathed to Ayurveda by the Sankhya system, ideas related to the material nature of the world were given by the Vaisheshikas. Their pancha-bhuta theory facilitated a practical, albeit rudimentary, classification of matter, both bodily and environmental. Ayurveda ingeniously wedded the Sankhya idea of triguna with the Vaisheshika theory of pancha-bhuta to produce its tridosha doctrine - a rough-and-ready model that could classify illnesses and facilitate therapeutic choices thereafter (vide note $e^{*}$.

Leading exponents of Indian philosophy have always been straightforward about the nature of science-related theories contained in the philosophical systems. Professor M Hiriyanna clarifies that "the value of the science contained in the systems cannot be great now when experimental methods of investigation have advanced so much" (17). Swami Ranganathananda concurs: "In the Upanishads, we get an intelligible body of verified and verifiable spiritual insights mixed with a mass of cosmological speculations relating to the nature and origin of the universe. While the former has universal validity, and has a claim on human intelligence in all ages, the latter forswears all such claim. All positivistic knowledge contained in any literature, including religious literature, is limited and conditioned by the level of contemporary scientific knowledge. Modification and even scrapping, of much of this knowledge due to subsequent advances has affected the truth-validity of much of man's literary heritage, including his religious and philosophical ones." (18)

In spite of these clarifications by eminent philosophy scholars, Ayurvedic academia continued to treat Ayurveda's quasi-philosophical theories as infallible scientific truths. Theories based on simple intuitive reasoning were misconstrued as profound mystical insights, thereby rendering them unmodifiable. The dosha theory, relevant in current times only as a heuristic technique, was dogmatically supposed to retain its old relevance as a sophisticated pathophysiological law. This shocking misconception has been highly influential in shaping the official approach to Ayurveda. The Ayurveda syllabus, its textbooks, and research journals are all reflective of this influence.

The historical roots of such misconceptions have been outlined in the essay "The History of a Superstition" (19). The following passage is excerpted from there: 
The story dates back to almost a hundred years. In 1921, the then Government of the Madras presidency constituted a committee to report on the question of recognition and encouragement of the indigenous systems of medicine. The committee, under the chairmanship of Muhammad Usman, did exemplary work and produced an elaborate report that is even today valuable for the vivid pictures of Ayurvedic practice it documents.

Captain G Srinivasa Murti, a well regarded doctor trained in modern medicine, was its secretary. His memorandum, appended to the committee's report, is perhaps the earliest formal attempt at juxtaposing Ayurveda with western medicine and the modern scientific method. It also, ironically, represents the earliest intellectual efforts to institutionalise the science-throttling worldview elaborated above. What he unwittingly wrote a hundred years ago continues to be the governing worldview in the Ayurvedic world even to this day: "The methods by which the Hindus sought to cognise things beyond the range of the senses, differed in one vital respect from the methods of the West; in modern science, we seek to overcome the limitations of senses by equipping ourselves with various external aids like the microscope, the telescope, the spectroscope and the like; the Hindus however sought to effect the same results, not by providing their senses with external aids, but by improving their own internal organs of sense (sic), so that their range of perception may be extended by any desired degree; the way of effecting this improvement was by exercising the senses in certain ways indicated in the scriptures and taught by the Guru to the shishya when he was ready for it." After trying to show some parallels between Indian philosophical thought and modern physics, he goes on to hope, "When one realises how fully some of these theories have been justified by the most recent events in modern science, one cannot help entertaining the feeling that, as some theories have already proved true, the same may happen in the case of others as well."

This idea, supported by neither serious science nor serious philosophy, gained quick acceptance in the ayurvedic world. Stalwarts like Achanta Lakshmipathi and Pandit Shiv Sharma seconded the idea wholeheartedly. The New Age fancy of 'discovering' the ideas of quantum physics in Indian philosophical literature also contributed to the view gaining currency. What's more, the Ayurveda syllabus was formulated on its basis and with this, the idea graduated to become the official Ayurvedic view. The most serious repercussion of this view was to keep Ayurvedic theories out of the scope of scientific scrutiny and this, in the fantastical hope that science has yet to adequately advance to be able to evaluate them! The official Ayurvedic view thus came in brazen dissonance with the universality of the scientific method.

The same old misconceptions relating to the supposed esoteric character of Ayurvedic epistemology get peddled often. Ayurvedic journals unabashedly carry articles that strengthen such misconceptions by suggesting silly connections between ancient Ayurvedic theories and modern quantum physics (20). The Ayurvedic academia is dominated by mystifiers who rejoice in presenting mysticisms as philosophy and science. When called to account, they seek refuge in the explanation that the truth of these theories can be realised only by achieving deep yogic states! A few others respond by resorting to ludicrous intellectual gymnastics of somehow extracting current scientific information from millennia-old aphorisms (21).

These problems in academia's approach to Ayurveda have been pointed out by scholars of yesteryears. Debiprasad Chattopadhyaya, the well-known Marxist scholar, presented a masterly critique of Ayurvedic theories in his book "Science and Society in ancient India". Despite its ideological biases, this book is a good introduction to Ayurveda's epistemology (7). In his concluding remarks, Chattopadhyaya laments: "Later doctors of Indian medicine attach a sheer pragmatic value to the ancient drugs and decoctions and, practically oblivious of the marvellous science potentials or the theoretical achievements of the ancient doctors, go on dogmatically reiterating certain formulas about vayu, pitta and kapha as universal solvents of all pathogenic problems. The methodology of science once worked out is practically forgotten."

Priya Vrat Sharma is one of the best known translators of Ayurvedic classics. He has chronicled the history of Ayurveda in his voluminous Hindi book Ayurved ka vaignyanik itihas (22). In its introduction, he also laments: "The West appears to look onward while the East appears to be stuck in the past. The West too had ideas analogous with those of bhutas and doshas about 2500 years ago. It gradually jettisoned them away as a result of free thinking. Ayurveda however still treats these antiquated ideas as unmodifiable gospel truths."

Such well-reasoned criticism coming from respectable scholars too has had no impact on the Ayurvedic establishment. It has been convenient for them to ignore uncomfortable truths. All in all, straight-thinking has little place in this field. Can enhanced funding and publicity campaigns by the government ever remedy the dearth of a vibrant intellectual resource?

The sad effects of all this are fourfold:

i. As ancient theories are wrongly seen as perfected biological laws, diagnosis and management of illnesses become suboptimal (23). This has led to the erosion of trust people have in Ayurveda. When the quality of a science suffers, a trust-deficit in it naturally follows.

ii. Practices supposedly rooted in nebulous theories are hard to research. Such theories do not make definitive predictions; when theoretical predictions become vague, research designs to verify practices 
purportedly based on them cannot be expected to have unanimous approval. An article in Nature on Traditional Chinese Medicine (TCM) rightly notes: "To truly modernise Chinese medicine, we must first demystify its theories" (24). But, despite half-acentury's existence, the Central Council for Research in Ayurvedic Sciences (CCRAS) has managed to neither verify/falsify nor modify core Ayurvedic theories.

iii. Students with a genuine interest in Ayurveda lose their careers in an ecosystem that legitimises superstitions and incentivises scientific dullness. The "esoteric epistemology" of Ayurveda has fossilised ancient physiological and pathological conjectures. To learn by rote at the university level that semen is produced in the bone marrow or that the blood acquires its redness in the stomach would be an intellectual dishonesty that a sensitive student would ever shy away from (25). Mediocre students, unable to make sense of the subject, helplessly resort to the practice of modern medicine. In fact, most Ayurveda graduates either practise modern medicine or quit medical practice altogether.

iv. The great legacy of Ayurvedic sages and their path breaking advances towards evidence-based reasoning get unjustifiably soiled.

One hopes that this fourfold tragedy in the name of Ayurveda ends soon.

\section{Traditional Chinese Medicine}

Traditional Chinese Medicine (TCM) is the Chinese analogue of Ayurveda. A few remarks on the happenings in this field would not be out of place.

TCM drew the world's attention when the 2015 Nobel Medicine prize was awarded to Tu Youyou for her discovery of the life-saving anti-malarial drug artemisinin. The cue to her discovery came from a line she read in a 1700-year-old treatise of TCM on the use of the herb Artemisia annua L. In a commentary published in Nature Medicine, Tu Youyou emphasised that her discovery "represents only a sliver of the gifts or potential gifts Chinese medicine has to offer" (26). If anything, this achievement underscores the importance of studying and researching ancient medical treatises scientifically.

TCM appears to have strengths and weaknesses similar to those of Ayurveda; it is surrounded by similar misconceptions too. A detailed treatment of these topics is beyond the scope of this essay. Suffice it to quote one commentator who cautions: "In any case, this body of purely empirical knowledge is nowadays widely flourishing in the US and in Europe as an alternative to Western Medicine and with the claim of being a unique, independent and comprehensive medical system, when in reality it is structurally-and perhaps historically -related to the health and safety beliefs of pre-Christian Europe; and without the prospect for an epistemological rupture, it will remain built upon rudimentary cognitive modalities, ancient metaphysics, and a symptomological view of disease" (27). These observations, when appropriately contextualised, apply to Ayurveda as well.

\section{Ayurveda awaits a new dawn}

A leading exponent of Indian thought memorably wrote, "When a new stage of progress is reached, the old is not discarded but is consciously incorporated in the new. It is this critical conservatism which marks Indian civilisation, as a whole, that explains its stability and constitutes its special strength. But in the process of being thus utilised, the old undergoes a vital transformation" (28). True to this spirit of critical conservatism, modern India has witnessed many great revivalist movements. These movements were modern in their outlook, yet firmly rooted in Indianness. The Bengal Renaissance that enriched the region's socio-cultural landscape is an example. The Navodaya movement accomplished a similar revival in Kannada literature. Individuals such as Pandurang Vaman Kane and V $\mathrm{S}$ Sukthankar in Maharashtra invested their scholarship upon reviving and interpreting ancient texts in the light of modern needs. Scholar-monks like Satchidanandendra Saraswati worked on bringing to the fore the rational character of Vedantic thought.

The time is ripe for Ayurveda to achieve such a revival too. Retaining its best elements, it must discard whatever is obsolete. Scientific attitude is best seen as a facilitator of this process. Charaka and Sushruta would have wholeheartedly blessed such a revival.

\section{Wise men of yore, we don't despise As tributes to them, their views we revise}

Acknowledgment: The thoughts and findings that this paper contains were fortunate to find their first audience in the great scholar Shatavadhani Ganesh. This paper is my tribute to his vast and deep learning.

\section{*Notes:}

The dosha theory in Ayurveda is a rough-and-ready, intuitive model that the sages devised to systematise their medical observations and experience. Akin to the ancient Greek idea of interpreting bodily functions and therapies in terms of four primary qualities (hot, cold, dry, wet), the dosha theory attempts to classify physiological functions, pathological syndromes and therapies in terms of a few basic qualities.

Illnesses, in this simplistic paradigm, are principally of two types: those that require nourishing measures to ameliorate them and those others that require famishing ones. Vata and Kapha were conjectured to be the doshas (literally, bodily faults) respectively underlying these two types of illnesses. Although the classics posit that these "bodily faults" are biological substances, they are defined invariably in terms of their qualities. Vata was dry, and therefore needed nourishing (wet) measures to neutralise it. Kapha was wet, and therefore required famishing (dry) measures to reduce it. Hot and cold, the other set of basic qualities, were 
accommodated into the scheme by positing Pitta as the dosha of heat; diminution of pitta meant illnesses due to cold. Thus, Vata, Pitta, and Kapha came to be regarded as the three basic illness-causing factors underlying multifarious human ailments. Essentially, the scheme was meant to interpret and classify all bodily functions, malfunctions, and therapies in terms of a few complementary qualities - wet and dry, hot and cold.

Ayurveda constructs an elaborate theory around doshas and their qualities. The lure of the theory is that it facilitates a synthetic interpretation (yukti) of diverse components related to diagnosis and therapy. Such diverse elements as body-types, foods, and mental states can all be interpreted in terms of doshas. For instance, a lean body-type is due to Vata; milk is a Kapha-enhancing food; and, anger is due to Pitta. The interpretation is not haphazard; it is built on a scheme that is the product of commonsensical (intuitive) reasoning.

But the theory also has aspects that are outright conjectural. Disregarding such aspects and treating the theory as a model robust enough to retain its old relevance as a complete law of pathophysiology has severely dented Ayurveda's scientific quality in current times. There is therefore an urgent need to restate the theory's value. An attempt has been made in the essay, "The Ayurvedic Dosha Theory - A Deconstruction." (Available from Confluence, the web-forum of the Indian Academy of Sciences: http://confluence.ias.ac.in/theayurvedic-dosha-theory-a-deconstruction/)

\section{References}

1. Wells HG. Primitive thought. In: A short history of the world. England: Penguin Books; 2006.

2. Yadavasharma, ed. Sutrasthanam. In: Charaka Samhita. New Delhi: Munshiram Manoharlal Publishers; 1992.

3. Doniger W. Vedas. In: Encyclopaedia Britannica [Internet] Available from: https://www.britannica.com/topic/Veda

4. Valiathan MS. Evolution of the healing art in India. In: Towards Ayurvedic Biology. Bengaluru: Indian Academy of Sciences; 2006.

5. Editors. Ayurveda. In: Encyclopaedia Britannica [Internet]. Available from: https://www.britannica.com/science/Ayurveda

6. Yadavasharma, ed. Vimanasthanam. In: Charaka Samhita. New Delhi: Munshiram Manoharlal Publishers; 1992.

7. Chattopadhyaya DP. Methodology and epistemology. In: Science and Society in Ancient India. 1977.

8. Yadavasharma, ed. Siddhisthanam. In: Charaka Samhita. New Delhi: Munshiram Manoharlal Publishers; 1992.
9. Das Gupta SN. History of Indian Philosophy. Delhi: Motilal Banarsidas; 1997.

10. Yadavasharma, ed. Chikitsasthanam. In: Sushruta Samhita. Varanasi: Chaukhamba Surabharati Prakashan; 2003.

11. Yadavasharma, ed. Uttaratantra. In: Sushruta Samhita. Varanasi: Chaukhamba Surabharati Prakashan; 2003.

12. Valiathan MS. The Legacy of Susruta. Hyderabad: Orient Longman; 2007.

13. Rashtriya Ayurveda Vidyapeeth. Interactive workshop on Evidence based clinical practices in Ayurveda. New Delhi: RAV; 2009. p. 142.

14. Traub O. The science of medicine. In: MSD Manuals Consumer version (Internet). 2018.

15. Lakhotia SC. Ayurvedic Biology: An unbiased approach to revisit and rationalise the concepts and practices of Ayurveda. Proc Indian Natn Sci Acad. 2016 Mar; 82(1) 1-3.

16. Ganesh R. The tradition of Kshaatra in India. Prekshaa.in [Internet] 2019 May 27[cited 2021 Aug 31]. Available from: https:// www.prekshaa.in/article/ideal-indian-tradition-kshatra-neededtoday\%E2\%80\%99s-democracy

17. Hiriyanna M. Age of the systems. In: Outlines of Indian philosophy Delhi: Motilal Banarsidas; 2009. p.184.

18. Ranganathananda Swami. Introduction. In: The message of the Upanisads. Mumbai: Bharatiya Vidya Bhavan; 2001.p. 4.

19. Krishna GL. The history of a superstition. Curr Sci. 2019 Jul 10[cited 2021Aug 31]. 117(1):9. Available from: https:// www.currentscience.ac.in/Volumes/117/01/0009.pdf

20. Sharma, H. Correlation of Physiological principles of Ayurveda with Spin Types of Quantum Physics. Annals Ayurvedic Med. 2018; 7 (3-4): $72-4$.

21. Sharma PV. Review of: Dwarakanath C. Digestion and Metabolism in ayurveda. Indian Journal of History of Science (IJHS). 1969; 4(1-2): 15860.

22. Sharma PV. Preface. In: Ayurved ka vaijnanik itihas [Scientific History of Ayurveda].Varanasi: Chaukhambha Orientalia.

23. Krishna GL. The holism versus reductionism conundrum. Confluence, the web-forum of the Indian Academy of Sciences. 2020 Aug 13[cited 2021 Aug 31]. Available from: http://confluence.ias.ac.in/ the-holism-versus-reductionism-conundrum/

24. Qiu J. China plans to modernize traditional medicine. Nature. 2007 Apr 4[cited 2021Aug 31];446: 590-1. https://doi.org/ 10.1038/446590a.

25. Krishna GL. Ayurveda's bane. The Hindu. 2018 Apr 15 [cited 2021 Aug 31]. Available from: https://www.thehindu.com/opinion/open-page/ ayurvedas-bane/article23540373.ece

26. Tu Y. The discovery of artemisinin (qinghaosu) and gifts from Chinese medicine. Nature Med. 2011 Oct; 17(10):1217-20. Doi.org/ 10.1038/nm.2471.

27. Kavoussi B. Chinese Medicine: A Cognitive and Epistemological Review. Evid-Based Complement Alternat Med. 2007 Sep;4(3):293-8. doi: 10.1093/ecam/nem005.

28. Hiriyanna M. The value of Sanskrit learning and culture. In: Popular essays in Indian philosophy. Bengaluru:W.I.S.E. Words; 2017. 